\title{
Comparison of the effect of two internal fixation methods for proximal clavicle fractures
}

\author{
DHaining $X u^{1}$ \\ (iD) Yan Nie \\ Lifang Han ${ }^{1}$ \\ Liang Li ${ }^{1}$ \\ (D) Haitao Sui ${ }^{1}$
}

1. Department of Orthopaedics, Dongying People's Hospital, Dongying, Shandong 257091 China.

http://dx.doi.org/10.1590/1806-9282.66.5.654

\section{SUMMARY}

OBJECTIVE: To compare the effect of two internal fixation methods in the treatment of proximal clavicle fractures.

METHODS: Fifty patients with proximal clavicle fractures received surgical treatment. They were divided into a clavicular T-plate group and a double mini-plates group. The duration of the operation, blood loss during the operation, fracture healing time, and incision infection were evaluated between the two groups.

RESULTS: Operation time ( $t=2.063, P=0.058)$, intraoperative bleeding $(t=1.979, P=0.062)$, and fracture healing time $(t=1.082, P=0.066)$ were not statistically significant in the two groups. The patients were followed up for 12-18 months; one patient in the T-plate group had early removal of nails, but no clinical symptoms. At the 2-month follow-up, the ASES score in the double mini-plates group was significantly better than in the T-plate group ( $P<0.001)$; but at the 6-month follow-up, 1-week before removal of internal fixation and the final follow-up, the two groups had no significant differences $(P>0.05)$.

CONCLUSIONS: Both internal fixations have similar clinical results in the duration of operation, blood loss during the operation, and fracture healing time. The double mini-plates fixation presents advantages by reducing complications and speeding fracture healing; thus it is a more effective method to treat proximal clavicle fractures.

KEYWORDS: Clavicle/injuries. Fracture fixation. Fracture fixation, internal. Orthopedic procedures/methods.

\section{INTRODUCTION}

Proximal clavicle fractures represent one-third of all fractures involving the medial clavicle, accounting for $9.3 \%$ of the clavicle fractures. They are relatively rare in clinical practice, and more common in cases of larger direct violence. Non-surgical treatment may lead to deformed appearance, limited function, and other adverse consequences; thus the treatment effect is often not ideal. In recent years, scholars have carried out surgery for the treatment of proximal clavicle fracture $^{\mathrm{s} 1}$, but considering the complex characteristics of anatomical structures such as important nerves, blood vessels, organs, and so on in the dorsal side of the proximal clavicle, and no anatomical plate has been designed for the proximal clavicle. At present, there is no optimal internal fixation option for such fractures.From July 2014 to June 2019, fifty patients with proximal clavicle fractures treated by vertical internal fixation with T-plate and double mini plates 
were analyzed retrospectively in this study. By comparing the operation time, intraoperative hemorrhage, fracture healing time, and postoperative complications between the two groups, the differences in the functional recovery of the shoulder joint in different stages were analyzed. The report is as follows.

\section{METHODS}

\section{Subjects}

A total of 50 cases, 32 males and 18 females, aged from 22 to $62(41.4 \pm 23.5)$ years, were included in this study. According to the method of internal fixation, they were divided into a T-plate group (24 cases) and a double mini plates group (26 cases).

\section{Clinical signs}

Swelling of the proximal clavicle, obvious tenderness, palpable bone friction, and abnormal activity.

\section{Imaging examination}

CT three-dimensional reconstruction of imaging examination can provide the three-dimensional relationship between the proximal clavicle fracture and the displaced three-dimensional plane. Routine CT three-dimensional reconstruction examination before the operation can be the first choice for the diagnosis of proximal clavicle fracture and helps us prepare well before the operation and choose a more reasonable operation method ${ }^{2}$.

\section{Operative method}

The anesthesia approach for the operation is brachial plexus anesthesia or general anesthesia, and a beach chair position is used. The operation incision cuts the skin and subcutaneous tissues along the surface of the proximal clavicle to the end of the sternum, exposing the sternoclavicular joint, peeling off the periosteum above the fracture site, fully exposing the broken end of the fracture, cleaning up the embedded soft tissue at the broken end, exposing the broken end of the medial clavicle fracture, and reducing the sternoclavicular joint under direct vision; if necessary, it can be bound with absorbable non-invasive suture or Kirschner wire Temporary fixing. T-shaped plate group: after the fracture is reduced satisfactorily, the T-shaped plate is molded and placed at the far and near end of the fracture. 2-3 screws are attached to the near end of the fracture, and 3-4 screws are attached to the far end of the fracture for fixation. The screws should not enter the space of the sternoclavicular joint. In the double mini plates group, two pre-bent $2.0 \mathrm{~mm}$ or $2.5 \mathrm{~mm}$ mini plates were implanted above and in front of the clavicle after a satisfactory reduction of the fracture.

\section{Postoperative treatment}

The patients in the two groups had their shoulder joints suspended by a wrist band. One day after the operation, functional exercises such as forearm rotation, elbow flexion and extension, pendulum-like activities were performed; one week after the operation, patients were encouraged to perform functional exercises such as upper limb abduction and shoulder shrug; four weeks after the operation, appropriate lifting activities were performed and the range of activities was gradually increased; six weeks after the operation, normal shoulder non-weight bearing activities were resumed.

\section{Evaluation index}

The operative time, intraoperative hemorrhage, fracture healing time, and postoperative complications of the two groups were analyzed. The differences in shoulder pain and functional recovery were evaluated by the American Shoulder and Elbow Surgeons (ASES) ${ }^{3}$ Standard at 2 months, 6 months, and 1 week before internal fixation removal and the last follow-up.

\section{Statistical analysis}

SPSS 19.0 software was used for statistical analysis. The measured data were expressed by mean \pm standard deviation, and the mean index determined between the two groups was compared by students t-test; the comparison of the data was by the chisquare test, and $\mathrm{P}<0.05$ was considered as statistically significant.

\section{RESULTS}

The general characteristics of patients included in this study are summarized in Table 1 . The causes of injury were: direct violence in 38 cases, indirect violence in 12 cases. The Craig III group of fractures were: 21 cases of type II, 12 cases of type III, and 17 cases of type $V$. The time from injury to operation was 2-7 days. According to the method of internal fixation, patients were divided into a T-plate group (24 cases) and a double mini plate group (26 cases). There was no significant difference between the two groups $(\mathrm{P}>0.05)$. 


\section{Follow-up}

Fifty patients in both groups were followed up for 12 to 18 months. All achieved bone healing.

\section{Observation index}

Table 2 shows the operation time, intraoperative blood loss, fracture healing time, and ASES score of each period of the two groups. Bone healing was achieved at the last follow-up.

\section{Postoperative complications}

There were no complications such as wound infection, fracture around the steel plate, and fracture of steel plate in both groups. In the T-plate group, 1 case (1 / 24) had screw loosening but no clinical symptoms; in the double mini plate group, there were no complications; there was a significant difference in the incidence of complications between the two groups $(\mathrm{P}<0.05)$.

\section{Typical cases}

Case one, male, 39 years old, was treated with T-plate fixation for a closed fracture of the left distal clavicle (Craig III group III). CT before operation showed a clavicle fracture and displacement (Figure1A). X-ray at 6 months after the operation showed fracture reduction and good internal fixation (Figure1B). Case two, male, 32 years old, was treated with two mini plates to fix a closed fracture of the left distal clavicle (Craig III group V). CT before operation showed a clavicle fracture and displacement (Figure1C). X-ray at 6 months after the operation showed fracture reduction and good internal fixation (Figure1D). Case three, male, 45 years old, was treated with two mini plates to fix a closed fracture of the left distal clavicle (Craig III group II). Before the operation, CT showed a fracture and displacement of the clavicle (Figure1E). X-ray at 6 months after the operation showed fracture reduction and good internal fixation (Figure1F).

\section{DISCUSSION}

Our study found that the functional recovery of the double mini plate group was significantly better than that of the T-plate group. In the double mini plate group, not only the fixation of at least 3 screws is done at the distal and proximal ends of the fracture, but also the smaller size of the mini plates avoids the potential risk of skin bursting, which creates conditions for early rehabilitation exercises and recovery of shoulder joint function after the operation. In this study, there were no complications in the double mini plate group, indicating that the failure rate of the internal fixation and reduced loss rate were significantly smaller.

In view of the anatomic structure of the subclavian artery, subclavian vein, external jugular vein, 4-8 nerves and 1-2 nerves in the chest, conservative treatment is generally adopted for proximal clavicle fractures, but the traditional " 8 " bandage or sling leads to shoulder dysfunction in the long-term conservative treatment of proximal clavicle fractures. Even if functional exercise is encouraged, there will be a certain

TABLE 1. GENERAL CHARACTERISTICS OF PATIENTS INCLUDED IN THIS STUDY

\begin{tabular}{|c|c|c|c|c|c|c|c|c|c|}
\hline \multirow{2}{*}{ Group } & \multirow{2}{*}{$n$} & \multicolumn{2}{|c|}{ Gender } & \multirow{2}{*}{ Age(years) } & \multicolumn{3}{|c|}{ Craig III } & \multicolumn{2}{|c|}{ Causes of injury } \\
\hline & & Male & Female & & II & III & V & direct & indirect \\
\hline T-plate & 24 & 18 & 6 & $44.2 \pm 26.1$ & 10 & 6 & 8 & 18 & 6 \\
\hline double mini plate & 26 & 19 & 7 & $43.7 \pm 33.9$ & 11 & 6 & 9 & 20 & 6 \\
\hline$t / \chi^{2}$ & & 2.647 & & 2.086 & & 1.064 & & 1.826 & \\
\hline$P$ & & 0.586 & & 0.692 & & 0.248 & & 0.326 & \\
\hline
\end{tabular}

TABLE 2. COMPARISON OF THE OBSERVATION INDEX BETWEEN THE TWO GROUPS

\begin{tabular}{|c|c|c|c|c|c|}
\hline & & T-plate group & Double mini plate group & $t / \chi^{2}$ & $P$ \\
\hline Operation time (min) & & $42.1 \pm 11.4$ & $43.2 \pm 12.1$ & 2.063 & 0.058 \\
\hline Intraoperative blood loss (ml) & & $22.6 \pm 11.8$ & $23.1 \pm 10.6$ & 1.979 & 0.062 \\
\hline Fracture healing time (month) & & $5.3 \pm 1.2$ & $5.1 \pm 1.6$ & 1.082 & 0.066 \\
\hline \multirow{4}{*}{ Score of ASES } & Time A & $68.0 \pm 2.1$ & $76.5 \pm 6.4$ & 2.686 & 0.027 \\
\hline & Time B & $84.3 \pm 3.4$ & $88.4 \pm 5.9$ & 1.086 & 0.214 \\
\hline & Time C & $90.1 \pm 2.6$ & $91.2 \pm 2.6$ & 1.045 & 0.268 \\
\hline & Time D & $90.2 \pm 2.7$ & $91.3 \pm 2.4$ & 1.026 & 0.296 \\
\hline
\end{tabular}

Note: Time A: Two months after operation; Time B: Six months after operation; Time C: One week before removal of internal fixation; Time D: Last follow -up. 
degree of fracture healing ${ }^{4}$. Throckmorton et al. ${ }^{5}$ followed up the conservative treatment of proximal clavicle fractures, and about $53 \%$ of the patients had pain symptoms. Therefore, conservative treatment has been gradually replaced by surgical treatment. More and more scholars believe that open reduction and internal fixation is the better choice for the treatment of proximal clavicle fractures. Because there is no specially designed steel plate for the special anatomic characteristics of the proximal clavicle, there are little methods to fix fractures of the proximal clavicle. Bourghli and Fabre ${ }^{6}$ reported that Kirschner wire was used to fix the proximal clavicle fracture, and good surgical results were achieved. Bartonícek et al. ${ }^{7}$ reported that the proximal clavicle fracture was fixed with steel wire, and no dysfunction was left after the operation. Sidhu et al. ${ }^{8}$ reported that patients with such fractures were fixed with distal clavicular plates on the same side, and the results showed that the fractures were completely healed. Although the extensive use of internal fixation has effectively improved the healing rate of the proximal clavicle fracture and functional recovery of patients, there is still no small controversy on the selection of the method for internal fixation ${ }^{8}$.

Although the steel plate and screws of the micro steel plate system are small, they can be fixed using multiple $2.0 \mathrm{~mm}$ or $2.5 \mathrm{~mm}$ screws in different directions to make the stability control more reliable. Double mini steel plates were placed vertically on two $90^{\circ}$ planes to form a beam structure, which also increased the fixation firmness of the diamond frame structure near the clavicle ${ }^{9}$. After anatomic reduction of the proximal clavicle fracture, two micro plates were placed vertically at the top and the front, and the distal and proximal clavicle fractures could be fixed with at least three screws. There is no interference and no involvement of the sternoclavicular joint, so patients can exercise shoulder joint function early after the operation. Stable fixation also provided favorable conditions for early functional exercise. The ASES score was better than that of the T-plate group at the 2 months follow-up. In this study, there were no complications such as screw loosening, fracture around the plate, and nonunion in the double mini plate group. Therefore, the author believes the following points should be paid attention to in the treatment of proximal clavicular fracture with double mini plate technology: (1) operate gently during reduction to avoid further comminution of fracture in patients

\section{FIGURE 1}

A
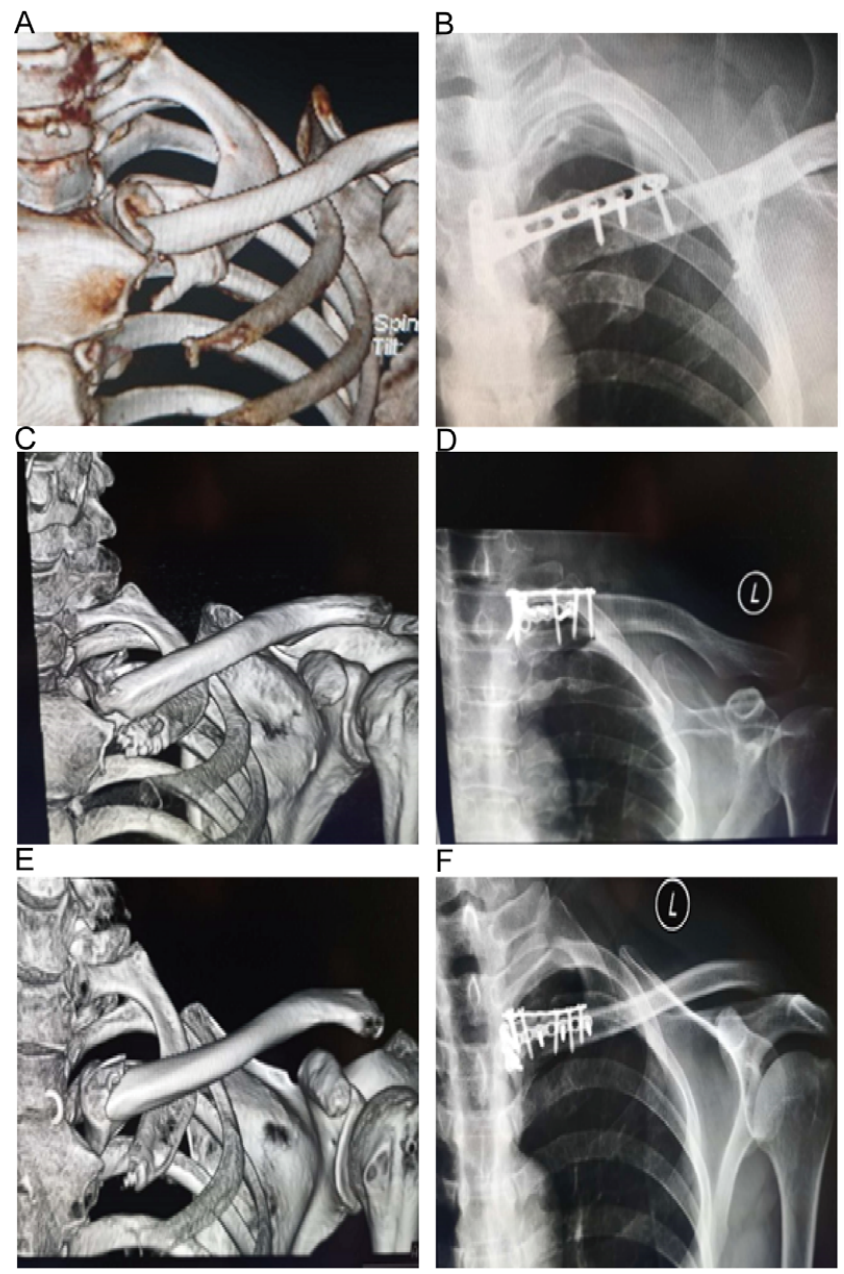

with osteoporosis; (2) in order to prevent the loss of clavicle length and rotation deformity, realize an anatomical reduction of fracture in the sternoclavicular joint. At the same time, avoid too much incision and separation to affect the stability of the sternoclavicular joint; (3) pre-bend the mini steel plate properly to make it more attached to the clavicle; (4) screw at least three screws into the proximal end of the fracture for fixation; (5) pay attention to the angle when screwing in to prevent the screw from entering the sternoclavicular joint space.

\section{CONCLUSION}

Both internal fixation methods have similar clinical results in the duration of operation, blood loss during the operation, and fracture healing time. The double mini-plates fixation provides advantages regarding a reduction of complications and faster fracture healing; therefore, this is a more effective method to treat proximal clavicle fractures. 


\section{Conflict of interest}

The authors declare no conflicts of interest.

Author Contributions

All authors contributed to the data analysis, drafting and revision of the article, gave final approval of the version to be published, and agreed to be accountable for all aspects of the work.

Haining $\mathrm{Xu}$ and Yan Nie contributed equally to the work.

\section{RESUMO}

OBJETIVO: Comparar o efeito de dois métodos de fixação interna no tratamento de fraturas da clavícula proximal.

MÉTODOS: Cinquenta pacientes com fraturas da clavícula proximal receberam tratamento cirúrgico. Eles foram divididos em um grupo de placa T clavicular e um grupo de miniplacas duplas. A duração da operação, perda de sangue durante a operação, tempo de cura da fratura e infecção na incisão foram avaliados nos dois grupos.

RESULTADOS: $O$ tempo de operação $(t=2,063, P=0,058)$, perda de sangue durante a operação $(t=1,979, P=0,062)$ e tempo de cura das fraturas ( $t=1,082, P=0,066)$ não foram estatisticamente significativos nos dois grupos. Os pacientes foram acompanhados por $12-18$ meses; um dos pacientes do grupo da placa T teve retirada antecipada dos parafusos, mas não apresentou sintomas clínicos. Aos dois meses de acompanhamento, a pontuação ASES no grupo de miniplacas duplas foi significativamente melhor do que a do grupo de placas $T(P<0,001)$. Porém, no acompanhamento de seis meses, uma semana antes da remoção da fixação interna e do acompanhamento final, os dois grupos não apresentavem diferenças significativas $(P>0,05)$.

CONCLUSÃo: Ambas técnicas de fixação interna têm resultados clínicos semelhantes quanto a duração da operação, perda de sangue durante a operação e tempo de cura da fratura. A fixação de miniplacas duplas apresenta vantagens quanto a redução das complicações e cura mais rápida da fratura, sendo, portanto, um método mais eficaz para tratar fraturas da clavícula proximal.

PALAVRAS-CHAVE: Clavícula/lesões. Fixação de fratura. Fixação interna de fraturas. Procedimentos ortopédicos/métodos.

\section{REFERENCES}

1. Salipas A, Kimmel LA, Edwards ER, Rakhra S, Moaveni AK. Natural history of medial clavicle fractures. Injury. 2016;47(10):2235-9.

2. Wang Y, Jiang J, Dou B, Zhang P. Inverted distal clavicle anatomic locking plate for displaced medial clavicle fracture. Arch Orthop Trauma Surg. 2015;135(9):1241-5

3. King GJ, Richards RR, Zuckerman JD, Blasier R, Dillman C, Friedman RJ, et al. A standardized method for assessment of elbow function. Research Committee, American Shoulder and Elbow Surgeons. J Shoulder Elbow Surg. 1999;8(4):351-4.

4. Rieser GR, Edwards K, Gould GC, Markert RJ, Goswami T, Rubino LJ. Distal-third clavicle fracture fixation: a biomechanical evaluation of fixation. I Shoulder Elbow Surg. 2013;22(6):848-55.
5. Throckmorton T, Kuhn JE. Fractures of the medial end of the clavicle. Shoulder Elbow Surg. 2007;16(1):49-54.

6. Bourghli A, Fabre A. Proximal end clavicle fracture from a parachute jumping injury. Orthop Traumatol Surg Res. 2012;98(2):238-41.

7. Bartonícek J, Fric V, Pacovský V. Displaced fractures of the medial end of the clavicle: report of five cases. J Orthop Trauma. 2010;24(4):e31-5.

8. Sidhu VS, Hermans D, Duckworth DG. The operative outcomes of displaced medial-end clavicle fractures. I Shoulder Elbow Surg. 2015;24(11):1728-34.

9. Kim KC, Shin HD, Cha SM. Surgical treatment of displaced medial clavicle fractures using a small T-shaped plate and tension band sutures. Arch Orthop Trauma Surg. 2011;131(12):1673-6. 